\begin{tabular}{|c|c|}
\hline & $\begin{array}{c}\text { International Journal of Current Research } \\
\text { and Academic Review }\end{array}$ \\
\hline & $\begin{array}{c}\text { ISSN: 2347-3215 (Online) Volume } 6 \text { Number } 4 \text { (April-2018) } \\
\text { Journal homepage: http://www.ijcrar.com }\end{array}$ \\
\hline
\end{tabular}

doi: https://doi.org/10.20546/ijcrar.2018.604.008

\title{
A Brief on Applications of Titanium Dioxide
}

\author{
M. Durairasu and V. Indira* \\ Department of Zoology, Presidency College, Chennai - 600005, Tamil Nadu, India \\ *Corresponding author
}

\begin{abstract}
Titanium dioxide has been concentrated recently due to its efficient utilization in Dye sensitized solar cells which was first demonstrated by Graetzel. Apart from this, Titanium has its own applications in cosmetics such as sunscreens, pharmaceutics as antibacterial coatings, food products, tooth paste and also in other products such as plastics, papers and inks. It is also thermally stable therefore used in implants and in aeronautics, non - flammable and poorly soluble. It is a semiconductor that absorbs light and forms hydroxyl radicals when contacted with water. This phenomenon of titanium has been used in several applications and the present review deals with the brief application of titanium dioxide.
\end{abstract}

\section{Article Info}

Accepted: 07 March 2017

Available Online: 20 April 2018

\section{Keywords}

Anatase, Brookite, Hydroxyl radicals, Photoactivity, Rutile, Semi-conductor, Titanium dioxide

\section{Introduction}

Titanium dioxide is an important $\mathrm{n}$ - type semiconductor with wide band gap. They have many advantageous properties such as absorption of light, charge transport and surface adsorption which make them to be used in many industrial applications (Pan et al., 2013). They are biologically inert, relatively inexpensive and highly stable. Apart from these they are also found to have photoactivity and photostability (Valenica et al., 2013; Fujishama and Zhang 2006). These properties of Titanium dioxide make it to be used in several industrial manufacturing products. Since its commercial production in $11^{\text {th }}$ century, they have been used in cosmetics such as sunscreens, as pigments in paints, ointments and toothpaste (Pfaf 1999; Salvador et al., 2000; Zallen and Morret 2006; Braun et al., 1992; Yuran et al., 2005). The application of Titanium dioxide nanoparticles in photovoltaics was found when Fujishima and Honda (1972) discovered the phenomenon of photocatalytic splitting of water by Titanium dioxide electrode under UV light irradiation. Since the discovery, Titanium dioxide has been studied for its several light oriented phenomena such as photocatalytic degradation, Dye sensitized solar cells, Sensors etc. (Graetzel 2001; Hagfeldt and Graetzel 1995; Linsebiggler et al., 1995; Millis 1997). The present review deals with the titanium dioxide and its applications.

\section{Titanium dioxide}

As discussed earlier it is a semiconductor that finds its application in various industrial processes such as sunscreens, paints, toothpaste and also in photovoltaics such as Dye sensitized solar cells and biosensors. The Titanium dioxide that is used for these purposes exists in three forms as anatase, rutile and brookite (Fig. 1). Although they found to exist in three different forms, they are known to be found in eleven different forms. In all polymorphs of $\mathrm{TiO} 2$, titanium is in octahedral 
coordination, i.e., its coordination number equals six. However, the number of shared edges increases from two in rutile, to three in brookite, to four in anatase. It has been suggested (Evans 1966) that the relative stability in the bulk phase of these phases may be inversely related to the number of shared edges, i.e., rutile more stable than brookite, 4 which in turn is more stable than anatase. The structure of anatase and rutile is tetragonal, while that of brookite is orthorhombic (Banfield, Veblen et al., 1991; Kim, Enomoto et al., 1996).

\section{Applications of titanium dioxide}

As discussed earlier, titanium dioxide has been used in cosmetics, paints, toothpaste, cement and in photovoltaics (Fig. 2) which are discussed in brief as follows:

\section{Sunscreens}

Titanium dioxide is a predominant compound in sunscreens. Titanium dioxide blocks Ultra violet A (UVA) rays with a wavelength of $315-400 \mathrm{~nm}$ and Ultra Violet B (UVB) rays with a range of $280-315 \mathrm{~nm}$. $\mathrm{TiO}_{2}$ used in sunscreens are highly stable and are not decolourized by UV radiation. In sunscreens, they are coated with silica or alumina since when contacted with water $\mathrm{TiO}_{2}$ produces hydroxyl radicals which are potentially carcinogenic. Therefore the coating prevents the contact of titanium dioxide with water and also skin making them safe to be used.

\section{Cement}

Titanium dioxide were found to be added on to the surface of cements, tiles and paints to have sterilizing, deodorising and anti - fouling properties since $\mathrm{TiO}_{2}$ can form hydroxyl radicals when contacted with water and convert organic molecules to $\mathrm{CO}_{2}$ and water to which in turn destroys microorganisms. Several studies on using titanium dioxide in cements have been done. Chen and Liu (2010) found that treating cements with $\mathrm{TiO}_{2}$ gave the material resistance against traffic and natural weathering to pavements. In contrast, a study on concrete blocks made with $\mathrm{TiO}_{2}$ showed that the dust, dirt, oil and grease that are deposited on the pavement over a period of time couldn't be removed by photocatalysis and the efficiency of $\mathrm{TiO}_{2}$ were found to decrease on time. It has also been found that the photocatalysis of $\mathrm{TiO}_{2}$ cannot be regained on washing with water (Chai Mei Yu 2003). However, research is still being conducted on making $\mathrm{TiO}_{2}$ resistant against traffic pollutants and natural weatherings on pavements by cement water coating with fine sand and $\mathrm{TiO}_{2}$ nanomaterials to the fresh concrete surface prior to curing (Hassan et al., 2010).

\section{Self - cleaning glass}

The first self - cleaning glass made with coating of anatase combined with complexing agents containing organic molecules was introduced during the year 2001. The organic molecules were found too act as ligands and bind to titanium ion with co-ordinate bonds which is an important process to convert titanium into soluble form to be spread over glass surface. After application of titanium coating the glass is heated to burn off the organic complexing agent leaving the anatase coating alone intact. Anatase absorbs UV light with wavelengths and activates titanium dioxide by exciting electrons to higher energy levels. The activated titanium dioxide reacts with water, generates hydroxyl radicals and breaks down organic molecules. The hydroxyl free radicals on the surface of the titanium dioxide increase the hydrophilic character of the glass and when it rains, the water runs off the glass in the form of a sheet and the dirt is washed off.

Fig.1 Different forms of $\mathrm{TiO}_{2}$
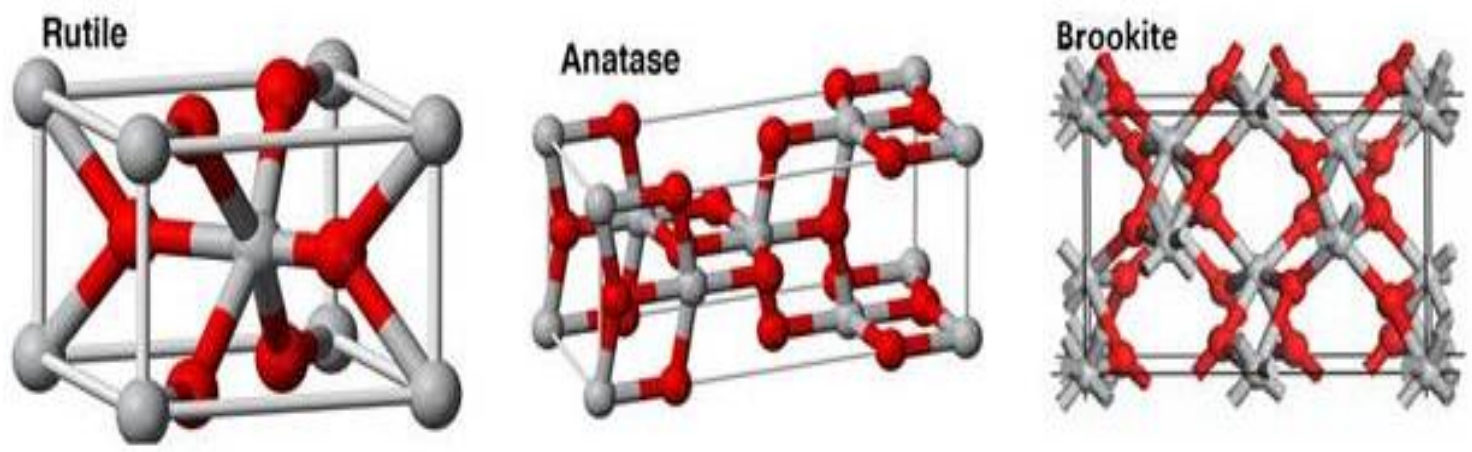
Fig.2 Applications of $\mathrm{TiO}_{2}$

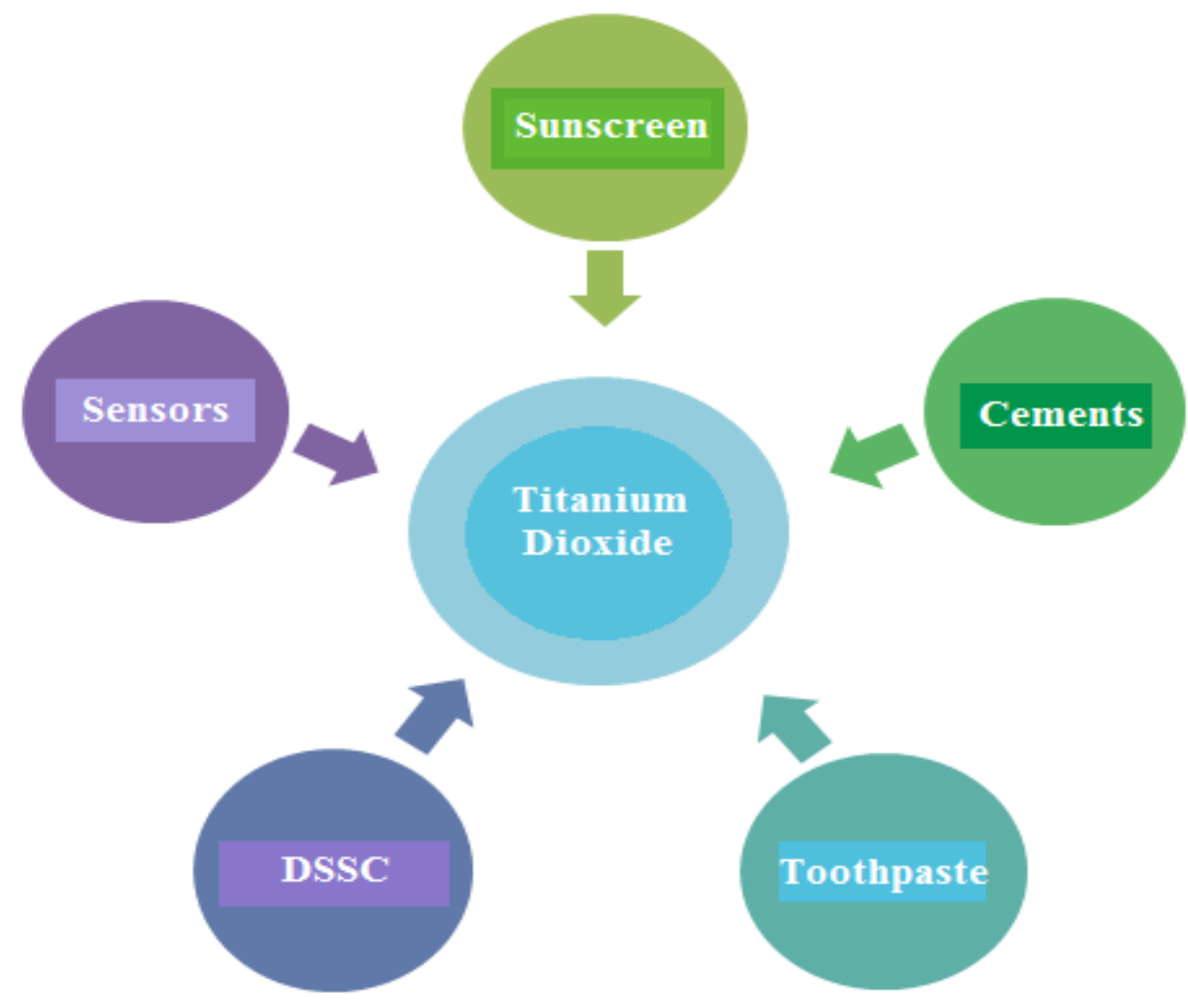

Fig.3 $\mathrm{TiO}_{2}$ in dye sensitized solar cells (DSSC)

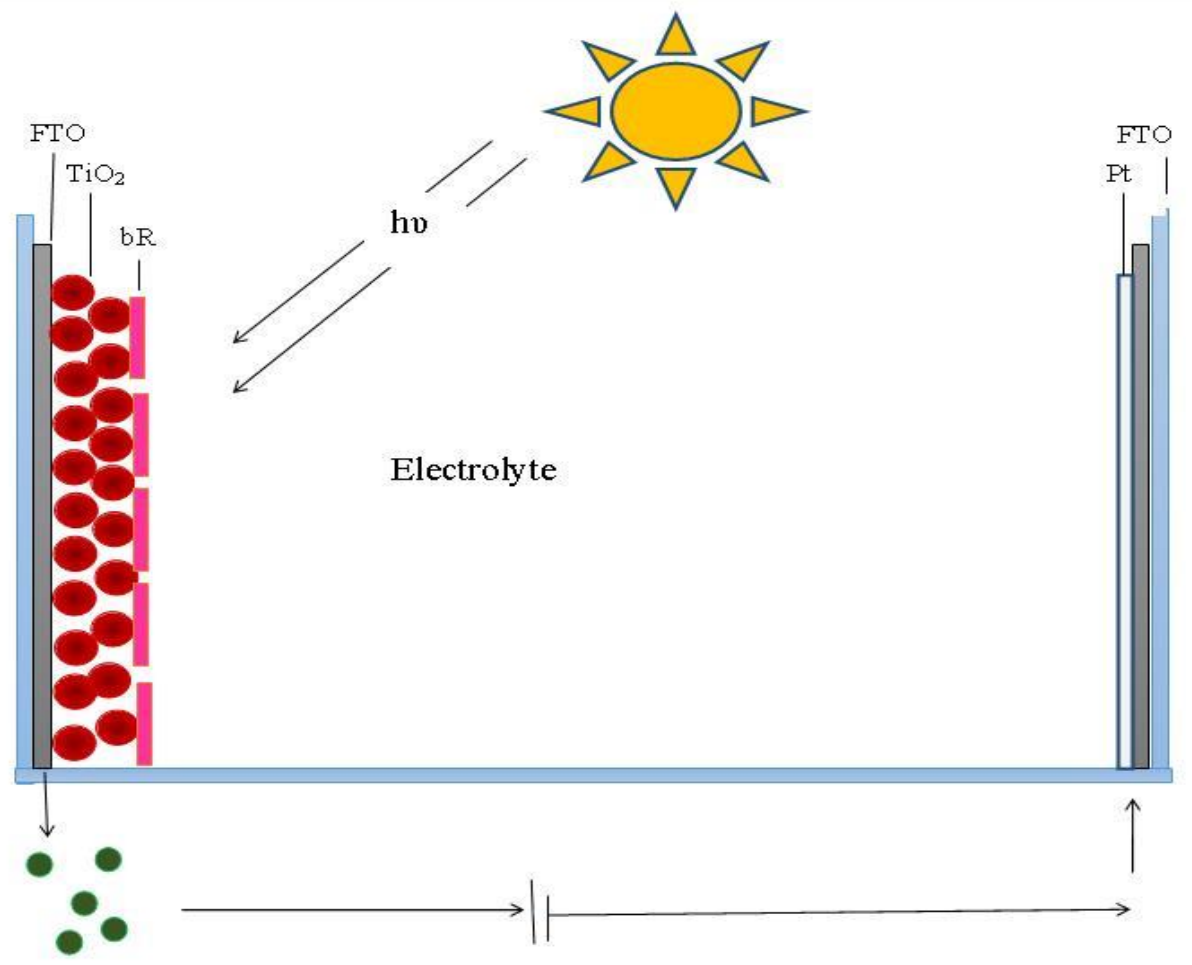

Electrons 


\section{Photocatalysis}

Graetzel invented the modern photovoltaic cells to convert solar energy into electrical energy called as Dye Sensitized Solar Cells or Graetzel cells (Fig. 3). The main nanocomposite used in solar cells especially the Dye Sensitized Solar Cells (DSSC) is Titanium dioxide. Titanium being excellent conductor of solar energy they have been used extensively and they have been used alone or in with combinations. The Bio sensitized solar cell can act as a perfect alternative for chemical and toxic metal derived photovoltaics that is used in DSSC. BSSC is a protein or natural pigment based solar cell which functions exactly like a conventional solar cell and promotes energy production (Chang et al., 2008). Even in $\mathrm{BSSC}$ cells, $\mathrm{TiO}_{2}$ is used as photosensitizer. Naturally, the pigment has utmost stability to high $\mathrm{pH}$ and temperature which is a better quality to be used in Dye Sensitized Solar Cell (DSSC) in India. The BSSC is produced by immobilizing naturally derived pigment onto $\mathrm{TiO}_{2}$ nanocrystalline ceramic film which is coated onto fluorine doped tin oxide. The resultant will be $\mathrm{FTO} / \mathrm{TiO}_{2} /$ Pigment and it acts as a working electrode. This BSSC solar panel will be using the best of solar energy to its maximum in producing electricity.

Titanium dioxide was found to have unique behaviour such as improved mechanical and stabilizing properties. When adding certain nanofillers and nano-coatings, they can be tailored to modify their surface properties. From these variations, their physical and functional properties also changes and can be used for several applications such as automotive and solar energy including bio/chemical sensing, electronic devices, drug delivery, microwave absorbing device etc. From these, it has been clear that $\mathrm{TiO}_{2}$ will be future material of great importance and varied applications.

\section{References}

Banfield, J.F., Veblen, D.R., et al., 1991. The identification of naturally-occurring $\mathrm{TiO}_{2}$ (B) by structure determination using high-resolution electron-microscopy, simulation, and distance-leastsquares refinement. American Mineralogist, 76 (34), 343- 353.

Braun, J.H., Baidins, A., Marganski, R.E. 1992. $\mathrm{TiO}_{2}$ pigment technology: a review. Prog. Org. Coat., 20, $105-138$.

Chai-Mei Yu, J. 2003. Deactivation and Regeneration of Environmentally Exposed Titanium Dioxide $\left(\mathrm{TiO}_{2}\right)$ Based Products. Testing Report Departmental Order
Ref. No. E183413, Environmental Protection Department (EPD), HKSAR.

Chang, C.W., Chang, C.H., Lu, H.P., Wu, T.K. and Diau, E.W.G. 2008. Fabrication and Photovoltaic Characterization of Bio-Sensitized Solar Cells Using Myoglobin-Based Sensitizers, J Nanosci. Nanotechnol, 8, 1-8.

Chen, M. and Liu, Y. 2010.NOx removal from vehicle emissions by functionality surface of asphalt road.J Hazard. Mater, 174, 375-379.

Evans, R.D. 1966. An Introduction to Crystal Chemistry, Cambridge, Cambridge University Press.

Fujishima, A. and Zhang, X. 2006. Titanium dioxide photocatalysis: present situation and future approaches. Comptes Rendus Chimie, 9(5-6), 750760.

Gratzel, M. 2001. Photo electrochemical cells. Nature, 414 (6861), 338 - 344.

Hagfeldt, A., Gratzel, M. 1995. Light-induced redox reactions in nanocrystalline systems. Chem. $R e V$., $95,49-68$.

Hassan, M. M., Dylla, H., Mohammad, L. N., and Rupnow, T. 2010. Effect of Application Methods on the Effectiveness of Titanium Dioxide as a Photocatalyst Compound to Concrete Pavement. Presented at 89th Annual Meeting of the Transportation Research Board, Washington, D.C.

Kim, D. W., Enomoto, N., et al., 1996. Molecular dynamic simulation in titanium dioxide polymorphs: Rutile, brookite, and anatase. J. American Ceramic Society, 79 (4), 1095-1099.

Linsebigler, A.L., Lu, G., Yates, J.T. Jr. 1995. Photocatalysis on $\mathrm{TiO}_{2}$ surfaces: Principles, mechanisms, and selected results. Chem. Rev., 95, $735-738$.

Millis, A., Le Hunte, S. 1997. An overview of semiconductor photocatalysis. J. Photochem. Photobiol. A, 108, 1 - 35.

NPG Asia research highlight, 2009

Pan, X., Yang, M., Fu, X., Zhang, N. and Xu, Y. 2013. Defective $\mathrm{TiO}_{2}$ with oxygen vacancies: Synthesis, properties and photocatalytic applications. Nanoscale, 5(9), 3601-3614.

Pfaff, G., Reynders, P. 1999. Angle-Dependent Optical Effects Deriving from Submicron Structures of Films and Pigments. Chem. ReV., 1999, 99(7), 1963 - 1982.

Salvador, A., Pascual-Marti, M. C., Adell, J. R., Requeni, A., March, J.G. 2000. Analytical methodologies for atomic spectrometric determination of metallic oxides in UV sunscreen creams. J. Pharm. Biomed. Anal., 22(36), 301 - 306. 
Uses of Titanium dioxide, RCS, Masterclass: $\mathrm{TiO}_{2}$ sheet, $6,1-5$.

Valencia, S., Vargas, X., Rios, L., Restrepo, G. and Marın, J.M. 2013.Sol-gel and low-temperature solvothermal synthesis of photoactive nano-titanium dioxide, J Photochem. Photobiol. A: Chem., 251, 175-181.

Yuan, S.A., Chen, W.H., Hu, S.S. 2005. Fabrication of
$\mathrm{TiO}_{2}$ nanoparticles/surfactant polymer complex film on glassy carbon electrode and its application to sensing trace dopamine. Mater. Sci. Eng. C, 25, 479 $-485$.

Zallen, R., Moret, M.P. 2006.The optical absorption edge of brookite $\mathrm{TiO}_{2}$. Solid State Commun, 137, 154 157.

How to cite this article:

Durairasu, M. and Indira, V. 2018. A Brief on Applications of Titanium Dioxide. Int.J.Curr.Res.Aca.Rev. 6(4), 5458. doi: https://doi.org/10.20546/ijcrar.2018.604.008 